\title{
The Codex Vratislaviensis of Philostratus' Life of Apollonius of Tyana
}

\author{
Gerard J. Boter \\ Vrije Universiteit Amsterdam, Department of Classics \\ g.j.boter@vu.nl
}

Received January 2019 | Accepted March 2019

Gottfried Olearius, on p. X of the preface to his edition of the complete works by Philostratus, mentions a ms. of Philostratus' Life of Apollonius of Tyana preserved in Breslau (modern Wrocław, Poland). ${ }^{1}$ He frequently refers to readings of the ms. in the notes to his edition of the Life (henceforward VA [Vita Apollonii]). C.L. Kayser mentions the ms. on p.X of the preface to his 1844 editio maior of Philostratus' Opera omnia, stating that a full collation of the ms. was made on his behalf by F. Jacobs. He points out that the ms. (for which he uses the siglum v; I use the siglum V) is closely related to Vaticanus graecus 1016 (Kayser's siglum $r$, my R), ${ }^{2}$ basing his conclusion on the readings common to the two mss. and the great lacuna they share in book 8; Kayser's conclusions are corroborated by my own findings. ${ }^{3}$ Kayser assigns $\mathbf{V}$ to the fifteenth century; Wachler 1828, $5^{1}$ and the catalogue of the Breslau Stadtbibliothek (p. 48) assign it to the sixteenth century. I have asked Rudolf Stefec, a specialist in the field of Greek palaeography, for his opinion; he thinks it probable that the ms. was written between $145^{\circ}$ and 1480 , possibly in Constantinople. $V$ once belonged to the sixteenth-century bibliophile Thomas Rehdiger (1540-1576), who

1 Olearius states that the ms. was preserved in the Bibliotheca Magdalensis but this statement is corrected in the catalogue of the library which was published in 1889. In the description of the ms. on p. 48 n. 1 we read: "Fallitur G. Olearius. Codicem nunquam bibliothecae Magdal. fuisse constat". In reality the ms. was preserved in the Stadtbibliothek in Breslau.

2 For a full description of $\mathbf{R}$, see Boter 2014, 22-23. $\mathbf{R}$ was copied by three scribes; the second of these has been identified as Isidorus of Kiev, who also owned the manuscript. The most recent watermarks in $\mathbf{R}$ suggest are attested for the fifties of the fifteenth century. It must have been written before 1463 , because Isidorus bequeathed $\mathbf{R}$ to the Vatican library on his death in 1463 . Like $\mathbf{V}$, $\mathbf{R}$ only contains $V A$.

3 See Boter 2009, 24, 41-42. 
lived in Breslau. His library, which contained some 300 mss., ${ }^{4}$ was acquired by the Breslau Stadtbibliothek in $1645,{ }^{5}$ where it eventually received the signature Rehdigeranus 39. After World War II the newly founded Wrocław University Library absorbed the treasures of (among others) the Stadtbibliothek.

The catalogue of 1889 gives the following codicological data: "Codex chartaceus forma oblonga maiore $(0,315 \times 0,220 \mathrm{~m}$.), foliorum 136 , septendecim quaternionibus constans; folium ultimum operculo adglutinatum est. Quaternionis septimi folia, quae media fuerant, nunc reliqua circumcludunt (fol. 4 ante fol. 1, fol. 5 post fol. 8); decimi qua ratione folia mutata sint, ab ipso scriba significatur (fol. 7 ante fol. 5). Fol. 130-136 vacua. Scriptus est codex saeculo XVI ab uno homine."

Marcel Richard, in the first edition of his Répertoire, states the following with regard to a number of Greek mss. of the Rehdiger collection: "En novembre 1955, 16 des 50 mss décrits dans ce catalogue ... étaient, sinon certainement perdus, du moins égarés." 6 In the third edition of the Répertoire, edited by Jean-Marie Olivier, we find the statement: "Les codd. ... 39 ... ont disparu." In this paper I will illustrate that the putatively lost Vratislaviensis has been recovered.

In the Supplément au Répertoire des bibliothèques et des catalogues de manuscrits grecs, published in 2018 by Olivier, there is a mention of a ms. containing VA in the Biblioteka Zgromadzenia Księzy Misjonarzy (Library of the Congregation of Missionary Fathers) in Cracow. ${ }^{8}$ Despite repeated efforts I have not been able to obtain reproductions of this manuscript. Because the mention in Olivier is reported to be due to Dr. Lesław Lesyk, I contacted him in order to obtain further information on the manuscript. Dr. Łesyk replied me that he is presently making a catalogue of Greek mss. preserved in Polish libraries, in collaboration with Dr. Katarzyna Kołakowska. ${ }^{9}$ Dr. Kołakowska wrote to me that she has briefly inspected the ms. in situ. ${ }^{10}$ She informed me that there is a flyleaf on the left cover of the ms. which reports its recent vicissitudes. At the end of World War II, when German soldiers were withdrawing from Breslau/Wrocław under the pressure of the Russian army, the soldiers tried to burn many books and mss. of the city's libraries. Some mss. were

4 See Wachler 1828, passim. The number of 300 mss. is mentioned on p. 25. The Philostratus manuscript is mentioned on p. 51 .

See Wachler 1828, 23-24.

6 Richard $1958,58$.

7 Olivier 1995, 846. See also Crisci 1983, 2; Boter 2009, 24; Stefec 2010, 66 n. 12; Boter 2014, 1 n. 1.

8 Olivier 2018, 653. I thank Rudolf Stefec for drawing my attention to this mention.

9 See Kołakowska 2015, Kołakowska and Łesyk 2018.

10 Dr. Łesyk informs me that he has also tried to obtain reproductions of the ms. from the library of the Congregation but his attempts have not been successful either. 
saved by bystanders and hidden in churches. In 1947, during the renovation of the organ in a small church in the village of Lutynia, the parish priest of the church, Mieczysław Krzemiński, found two manuscripts (the Philostratus ms. and a Latin one ${ }^{11}$ from the Rehdiger collection) in this organ and sent the two manuscripts as a gift to the Congregation in Cracow, where they are preserved nowadays.

Dr. Kołakowska kindly sent me six photographs she had made of the Cracow manuscript. I have collated the portions of VA preserved on these photographs. They contain the following passages (I refer to the page numbers in Kayser's

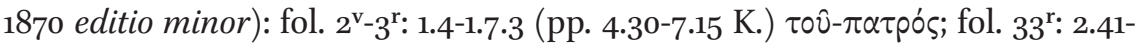

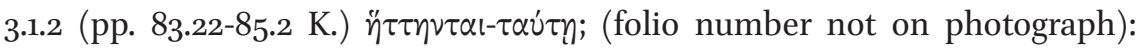

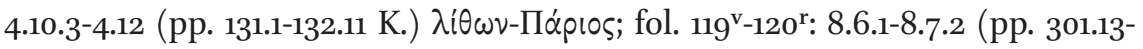

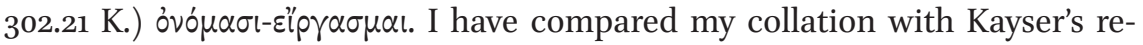
port of V in his 1844 edition. Many variants in the Cracow ms. noted by me are also reported by Kayser for his Vratislaviensis. I only mention variants for which $\mathbf{V}$ is the only witness quoted by Kayser; in some cases the same variant is found in $\mathbf{R}$ (which I have collated on microfilm). Some instances: 1.4 (p. 5.1

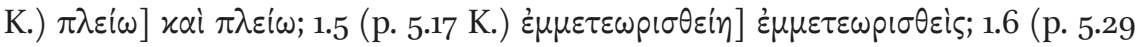

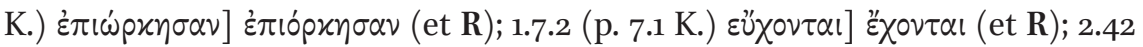

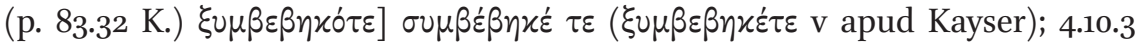
(p. 131.2 K.) $\dot{\pi} \pi \circ \tau \rho \circ \pi \alpha i o v] ~ \alpha \dot{\alpha} 0 \lambda \lambda \omega v i o v ; 4.11 .2$ (p. $131.18 \mathrm{~K}$.) $\pi \hat{\alpha} \sigma \alpha] \pi \hat{\alpha} \sigma \alpha \nu$ (et R); 4.11 .3

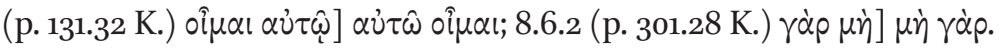

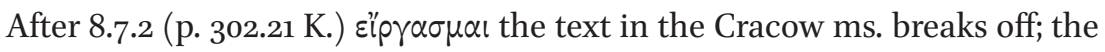
lacuna starts in line 5 of fol. $120^{\mathrm{r}}$; the rest of the page is left blank. For $\mathbf{V}$ Kayser ad loc. comments "hinc lacuna in v, usque ad p. $357 \mathrm{ed}$. Ol." In $\mathbf{R}$ the text of 302.21-330.2 (= p. 357 Ol.) $\mu \eta \delta^{\prime}-\hat{\eta} \tau \varepsilon$ is missing but there is no blank; $\dot{\alpha} \lambda \lambda^{\prime}$ (at 330.2) comes immediately after $\varepsilon^{\prime \prime p \gamma \alpha \sigma \mu \alpha l ~(a t ~ 302.21) . ~ I ~ a s s u m e ~ t h a t ~ a ~ q u i r e ~ h a d ~ g o t ~}$ lost in the common ancestor of $\mathbf{V}$ and $\mathbf{R}$; the scribe of $\mathbf{V}$ realised that there was something missing and left some open space; the scribe of $\mathbf{R}$ did not notice that there was a lacuna and went on copying the text of the next quire in the exemplar.

I have noted a number of variants which go unmentioned in Kayser's edition; I assume that in these cases Jacobs failed to notice the variants in $\mathbf{V}$ or that Kayser failed to report them. Here are some instances: 1.4 (p. $4.32 \mathrm{~K}$.)

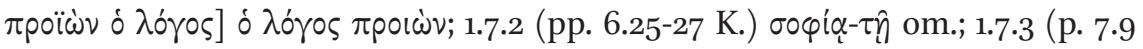

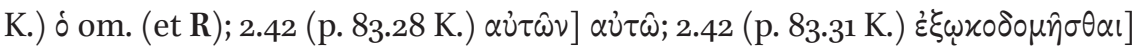

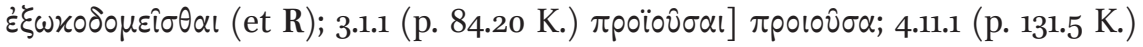

11 Unfortunately, nothing whatsoever is known about this Latin manuscript. 


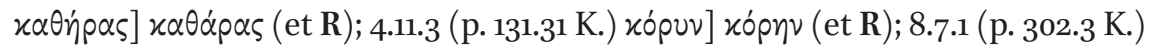

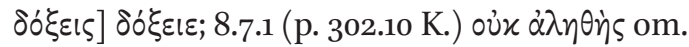

In the passages collated from the photographs Dr. Kołakowska sent me I have also collated $\mathbf{R}$ from microfilm. I have noted a number of separative errors in $\mathbf{R}$, which prove that $\mathbf{R}$ cannot have been the source of $\mathbf{V}$. Here are some

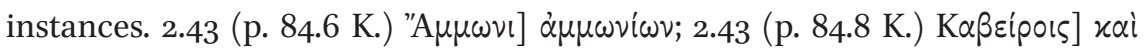

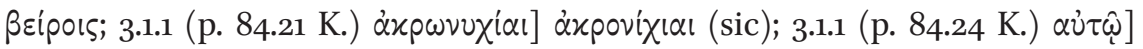

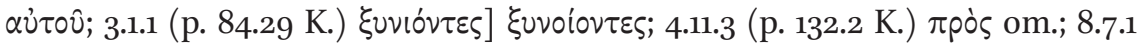

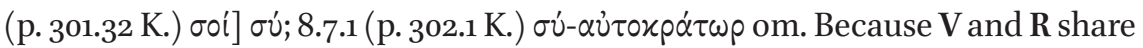
a number of conjunctive errors which separate them from the other mss. and because they both have separative errors against each other they are gemelli. In Boter 2009, 40-42 I have shown that the common source of $\mathbf{R}$ and $\mathbf{V}$ derives from Laurentianus 69.33 (F, written about $1000 \mathrm{AD}) .{ }^{12}$ Therefore the rediscovery of $\mathbf{V}$ will not have consequences for establishing the text and for the critical apparatus.

The combination of the data presented above leads to the obvious conclusion that the Cracow manuscript is identical with Kayser's codex Vratislaviensis, which now no longer should be regarded as lost. ${ }^{13}$

\section{Addendum}

After this miscellaneum was accepted for publication and published online, Dr. Łesyk informed me (email of 11 September 2019) that a catalogue of the Library of the Congregation of Missionary Fathers was published in 2018 in Cracow: Michalewicz, J., Katalog Archiwum Polskiej Prowincji Zgromadzenia Księży Misjonarzy Św. Wincentego a Paulo, Tom. II. Dr. Łesyk kindly sent me photographs of the title page and of p. 710. On this page, under the heading "VIII. 16. Literatura", we find a description of the two mss. which were found by the priest Mieczysław Krzemiński during the renovation of the organ in the church in Karczyce, in the parish Lutynia (not "Lutipcio", as the catalogue states with a query), in the county Środa Śląska.

Number 1 is the Latin ms., which contains ps.-Acro's commentary on Horace's Odes and a Life of Horace. It contains 108 numbered and four

12 For a full description of $\mathrm{F}$ see Boter 2014, 12-14.

13 I would like to express my warmest thanks to Dr. Łesyk and Dr. Kołakowska, without whose help I would not have been able to establish the identity of the codex Vratislaviensis and the Cracow manuscript. I also thank the anonymous reviewer for helpful remarks and suggestions. 
unnumbered folios; it measures $225 \times 310 \mathrm{~mm}$. and it is assigned to the sixteenth century with a query. The ms. has a white leather binding with a die stamping representing a deer standing on its hind legs. The rim has the text "Thomas Rediger-avec le temps". It has the stamp "V. Rhediserch. Stadt Bibliothek zu Breslau" and the old signature marks $1153 ; 81$. The ms. is mentioned by Wachler 1828,37 ; it is not recorded in the 1889 catalogue of the Breslau library.

Number 2 is the Philostratus ms. It has the same white leather binding with a die stamping of a deer, the same text on the rim and the same Breslau library stamp as the Latin ms. It has the old signature marks 115...; 39.

\section{Bibliography}

Boter, G.J. (2009). Towards a New Critical Edition of Philostratus' Life of Apollonius. The Affiliation of the Manuscripts. In: K. Demoen and D. Praet, eds., Theios Sophistes, Leiden/Boston, pp. 21-56.

Boter, G.J. (2014). Studies in the Textual Tradition of Philostratus' Life of Apollonius of Tyana. RHT 9, pp. 1-49.

Catalogus codicum Graecorum, qui in Bibliotheca urbica Vratislaviensi adservantur, a philologis Vratislaviensibus compositus, civitatis Vratislaviensis sumptibus impressus; accedit appendix qua gymnasii regii Fridericiani codices Graeci describuntur. Breslau, 1889 .

Crisci, E. (1983). Ricerche sulla tradizione manoscritta della Vita di Apollonio di Tiana di Filostrato, Dissertation, Sapienza University of Rome.

Kayser, C.L. (1844). Flavii Philostrati quae supersunt. Philostrati junioris Imagines. Callistrati Descriptiones. Zurich.

Kayser, C.L. (1870). Flavii Philostrati opera, Vol. ı. Leipzig.

Kołakowska, K. (2015). Greek Manuscripts in Poland. Part I: Kraków, Toruń, Elbląg. Littera Antiqua 10, pp. 4-24.

Kołakowska, K., and Łesyk, L. (2018). Współczesne badania nad manuskryptami Greckimi Krakowa źródłem nowych rezultatów badawczych. Roczniki Humanistyczne 56, pp. 127-146.

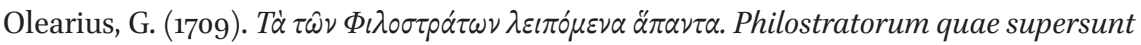
omnia: Vita Apollonii libris VIII. Vitae sophistarum libris II. Heroica. Imagines priores atque posteriores et epistolae. Acc. Apollonii Tyanensis Epistolae, Eusebii Liber adversus Hieroclem, Callistrati Descript. statuarum. Leipzig.

Olivier, J.-M. (1995). Répertoire des bibliothèques et des catalogues de manuscrits grecs de Marcel Richard. 3rd ed. Turnhout.

Olivier, J.-M. (2018). Supplément au Répertoire des bibliothèques et des catalogues de manuscrits grecs. Turnhout. 
Richard, M. (1958). Répertoire des bibliothèques et des catalogues de manuscrits grecs. Paris.

Stefec, R. (2010). Zur Überlieferung und Textkritik der Sophistenviten Philostrats. WS 123, pp. 63-93.

Wachler, A.W.J. (1828). Thomas Rehdiger und seine Büchersammlung in Breslau. Ein biographisch-literarischer Versuch. Breslau. 